\title{
Doğru Haber Alma Hakkı ve Sosyal Medya Dezenformasyonunu Doğruluk Payı ve Yalansavar ile Tartışmak
}

\author{
Ceren Yegen (Dr. Öğr. Üyesi) \\ Muş Alparslan Üniversitesi İletişim Fakültesi \\ c.yegen@alparslan.edu.tr
}

Başvuru Tarihi: 05.02.2018

Yayına Kabul Tarihi: 22.06.2018

Yayınlanma Tarihi: 30.07.2018

Öz

Bugünlerde sosyal medyanın önemli bir dezenformasyon mecrası olduğu tartışılmaktadır. Sosyal medya üzerinden dolaşıma sokulan sahte, doğru olmayan ya da doğruluğu teyit edilmemiş içerikler, bir haber/bilgi alma platformu da haline gelen sosyal medyayı doğru haber alma-verme tartışmalarının ortasında bırakmaktadır. "Fact-checking" yani "doğruluk kontrolü" de bugün dezenformasyon bağlamında önemli ve gerekli bir pratik olarak öne çıkmakta, özellikle Avrupa'da fact-checking organizasyonlarının sayısı her geçen gün artmaktadır. İlgili organizasyonlar haber, içerik ve beyanların doğruluğunu ölçerek, tartışarak doğruluk kontrolü gerçekleştirmektedir. Bu noktada içerik, haber yanlışlama platformlarının da geliștiğini belirtmek gerekmektedir. Türkiye'de ise Doğruluk Payı ve Yalansavar gibi oluşumlar doğruluk kontrolü bağlamında dikkat çekmektedir. Bu çalışmada da doğru haber alma hakkı noktasında Doğruluk Payı ve Yalansavar adlı oluşumlar incelecek, doğruluk kontrolünün nasıl yapıldığı ele alınacaktır. Çalışmada ayrıca sosyal medya dezenformasyonunu ölçmeyi amaçlayan alan araştırması da gerçekleștirilecektir.

Anahtar Kelimeler: Doğruluk Kontrolü, Sosyal Medya, İçerik, Haber, Doğruluk Payı, Yalansavar. 


\title{
To Discuss The Right to Receive Accurate News and Social Media Disinformation with Doğruluk Payı and Yalansavar
}

\author{
Ceren Yegen (Asst. Prof. Dr.) \\ Muş Alparslan University Faculty of Communication \\ c.yegen@alparslan.edu.tr
}

Date Received: 05.02.2018

Date Accepted: 22.06.2018

Date Published: 30.07 .2018

\begin{abstract}
It is being argued that social media is a major disinformation platform nowadays. Fake, inaccurate or unconfirmed contents that has been circulated through social media include the social media in discussions of taking and giving accurate news, which becomes a news/information receiving platform. "Fact-checking", that is, "accuracy control", is now an important and necessary practice in the context of disinformation, and the number of fact-checking organizations in Europe are increasing day by day. These organizations perform accuracy control by measuring and disputing the accuracy of news, contents and declarations. At this point, it is necessary to mention that platforms of content and news falsification have also developed. In Turkey, the formations such as Doğruluk Payı and Yalansavar draw attention in the context of accuracy control. In this study, Doğruluk Payı and Yalansavar will be examined as part of right to receive the accurate news, and how the accuracy control is done will be discussed. The study will also carry out a field study to measure the social media disinformation.
\end{abstract}

Keywords: Fact-Checking, Social Media, Content, News, Doğruluk Payı, Yalansavar. 


\section{Giriş}

Dezenformasyon, sosyal medya platformlarının gündelik yaşama yoğun dâhiliyeti ile kendisini bugünlerde sıkça gösterir olmuştur. Kullanıcı tarafından üretilen içeriklerin yurttaş gazeteciliği bağlamında sosyal medya platformlarında özellikle alternatif medya kuruluşları eliyle yer alması, sosyal medya içeriklerinin/haberlerin doğruluğunu ve güvenirliğini tartışmaya açmaktadır (Güz ve diğerleri, 2017). Sosyal medya dezenformasyonu birçok ülkede de tıpkı Türkiye'de olduğu gibi önemli bir tartışma konusudur. Facebook ve Google sahte haberlere karşı önlem alma yarışına girişse de (Greenslade, 2017; Foça, 2016; Wakabayashi ve Isaac, 2017), Facebook üzerinden yanlış bilginin hızlı yayılması gibi, çok daha fazla kişiyi etkilemesinin de Facebook'un doğrulama noktasındaki adımına gölge düşürdüğü düşünülmektedir (Foça, 2016). Bununla birlikte Google'ın 2017 Ocak sonu yaptığı bir açılama ile çok sayıda yayıncının aldatıcı içeriği nedeniyle reklam ağından yasaklandığına dikkat çektiğini (Wakabayashi ve Isaac, 2017) ve BuzzFeed News'in bir analizine göre, Facebook'ta gözlenen sahte haberlerden çoğunun ABD siyasetine odaklandığını da belirtelim (Silverman, 2016).

Türkiye'de ise Doğruluk Payı, Yalansavar, teyit.org ve Malumatfuruşgibigirişimler factchecking (doğruluk kontrolü) yaparak, yeni medya ile gelen dezenformasyona karşı durma çabasındadırlar (Foça, 2016). Foça'nın (2016) dikkatçektiği üzere, Avrupa'daki fact-checking organizasyonları üzerine eğilmiş olan Reuters Enstitüsü'nün “Digital News Report 2016: The Rise of Fact-Checking Sites in Europe" adını taşıyan raporu, bu noktada önemlidir. Rapora göre, aktif 113 fact-checking organizasyonu vardır ve bunların çoğu 2010 yılı sonrasında kurulmuştur. Rapor kapsamında ele alınan iki tip organizasyon vardır. İlk tip bir medya kuruluşuna bağlı olan organizasyonlar, diğeri ise kar amacı gütmeyen organizasyonlardır. Rapora göre, bu organizasyonların \%64'ü yaptıkları şeyin gazetecilik olduğunu düşünmektedir. Raporda belirtildiğine göre, siyasetçiler bu organizasyonları takip ediyor, organizasyonlar bir takım medya kuruluşları ile işbirliği içerisinde olmaktan ise tarafgirlik tartışmaları endişesiyle kaçınıyor. Raporda ayrıca söz konusu organizasyonların beyanına göre, demeci yanlışlanmış olan siyasetçilerden hiçbirinin hatasını kabul ettiği ve düzeltme yaptığına rastlanılmadığı da belirtiliyor (Foça, 2016). Görüldüğü üzere fact-checking bugün dezenformasyon noktasında bir hayli önemli ve gereklidir. Bu yüzden bu çalışmada doğru haber almayı göz eden fact-checking olgusu, yargısal örneklem ile seçilmiş olan ve Türkiye'de faaliyet gösteren Doğruluk Payı ve Yalansavar üzerinden ele alınacak, söz konusu girişimlerin doğruluk kontrolünü nasıl ve ne için yaptıkları ortaya konacaktır. Böylelikle dezenformasyon karşısında doğruluk kontrolünün nasıl işlediği açıklanacaktır. Çalışmada sınırlı kalmak adına iki girişimin incelenmesi tercih edilmiştir. Her iki girişim de doğruluk kontrolü noktasında Türkiye'de, özellikle Twitter'da aktif olduklarından tercih edilirken, çalışmada sosyal medya dezenformasyonunu ölçmeyi amaçlayan alan araştırması kapsamındaki derinlemesine görüşme tarihleri dıșında, bir periyod sınırlılığı bulunmamaktadır. Çalışmada incelenen bazı girişimlerin yetkilileri ile kişisel görüşmeler de yapılmış, edinilen bilgi ve veriler tarafımca kayıt altına alınmıștır.

\section{Haber ve Dezenformasyon}

Haber insanları bilgilendirme, eğlendirme, eğitme gibi misyonları olan kitle iletişim araçlarının, en önemli argümanıdır. Çünkü birey, sürekli kendisini ilgilendiren olaylar hakkında bilgi sahibi olmayı tahayyül eder. İnsan bilişi bir bilgisayar gibidir ve haber 
mahiyetinde olan, kendisini ilgilendiren beklenmedik olay ve gelişmeleri takip eder (Güz, 2005; Vaisey, 2008, 607; Tuchman, 1973, 111).

Haber içerisinde birçok değer barındırır. Tanımı ve ölçütleri gazeteciden gazeteciye değiştiği de iddia edilen haber, birtakım ortak özellikler bağlamında yalın olarak bireyleri ilgilendiren olay ve konular olarak tanımlanır (Ura, 1980). Haber söz konusu olduğunda dezenformasyon olgusu da gündeme gelir. Bilgi sağlayıcısı tarafından alıcıya eksik, yanıltıcı bilgilerin verilmesi ile gerçekleşen dezenformasyon, genellikle bir hükümet ya da bir başkası tarafından başlatılan sahte bilgi yayılması eylemini niteler (Tudjman ve Mikelic, 2003, 1514). Sahte bilgi yaymak suretiyle düşmanı zayıflatmayı amaçlayan dezenformasyonun, Rusya gibi ABD’nin de kullandığı bir taktik olduğu iddia edilir (O’Brien, 1989, 1). Özellikle savaş dönemlerinin önemli bir propaganda ayağı olan dezeformasyon, genellikle bir hükümet yetkilisi eliyle gerçekleşmiştir. Alıcıya ulaşan içeriğin onu etkileyip harekete geçireceği (Shoemaker ve Reese, 1996, 24-40) aşikâr olduğundan, propaganda ve dezenformasyon genellikle eyleme yönelik olmuştur.

Dezenformasyon genellikle misenformasyon ile karıştırılır, ama iki kavram ayırt edilmelidir (Kumar ve Geethakumari, 2014). Çünkü dezenformasyon, eksik, yanlış veya doğru olmayan bilgilerin bireyleri manipüle etmesi amacı ile yayılması iken, misenformasyonda söz konusu olan; gerçek bir bilginin eksik, yanlış veya taraflı olarak iletilmesidir (Tunç, 2010, 248).

Propaganda ve dezenformasyon denince akla kuşkusuz Soğuk Savaş Dönemi gelmektedir. Çünkü bu dönem yoğun dezenformasyon yaşanmıştır. Buna karşın Rusya'nın bu dönemden sonra dâhi, sürekli çeşitli şekillerdeki dezenformasyon çabaları ile batı düşüncesini etkilemeye çalıştığı iddia edilmektedir. Günümüzde dezenformasyonu besleyen kanallardan birisi de sosyal medyadır (Kux, 1985, 19; Uricchio, 2009).

\section{Doğru Haber Alma Hakkı ve Fact-Checking}

İletişime yeni medya ile gelen dijital (Turner, 2009, 75) etkileşimli biçim, siyasetçileri kullanıcılar ile yakın diyalog kurmaya adeta mecbur kılmıştır. Öyle ki siyasi parti ve aktörler bugün özellikle Facebook ve Twitter hesapları üzerinden seçmenler ile interaktif iletişim kurmaktadır. Twitter, Pakistan'da dâhi iletişimin önemli bir formu olmuştur. Örneğin Mayıs 2011 sonlarındaki Karaçi'deki deniz üssüne düzenlenen saldırı sırasında ordunun bir çağrı yapmamış olmasına ve donörlerin devam eden çatışma alanına gelmesinin tehlikeli olmasına karşın, birkaç tweet ile acil kan bağışı talep edildiği iddia edilmektedir (Michaelsen, 2011, 43-57).

Doğru haber alma bir yurttaş ve artık - sosyal medya bağlamında konuşulur ise bir "kullanıcı hakkı"dır. Fakat sosyal medya bugün, dezenformasyon boyutu ile doğru haber alma hakkına zarar verici bir rol oynayabilmektedir. Çünkü doğru olmayan kasıtlı birçok içerik, sosyal medya üzerinden kitlere hızla yayılabilmekte; enformasyon yoğunluğu ve kirliliği kullanıcının doğru haber alma hakkına ket vurabilmektedir. Sosyal medyanın günümüzde "son dakika haberciliğine" dönüştüğü iddia edilmektedir (Algül ve Sütcü, 2015, 31-32). Algül ve Sütcü’nün çalışmasına göre (2015) sosyal medya, konvansiyonel habercilikte haber ajanslarının gördüğü görevi görmekte, adeta kullanıcının ajansı olmaktadır. Bu durumun konvansiyonel haberciliğe en büyük etkisi, kuşkusuz sosyal medyanın, araç olan gazetenin 
aradan çıkarılmasını sağlamasıdır ve bu durum, konvansiyonel habercilik için profesyonelliğin zedelendiği yönündeki kayglları da beraberinde getirmektedir. Algül ve Sütcü'ye göre (2015, 31-32), sosyal medyanın haber ajansına dönüştüğü bir süreçte, kullanıcıya ulaşan içeriğin çok sayıda ve sürekli olmasının da dezenformasyonun gerçekleşmesinde rolü vardır.

Siyasiler adına açılan sahte hesaplar da dezenformasyona neden olduğu gibi, siyasileri zor durumda da bırakabilmektedir. Örneğin eski Pakistan Dış Iş̧leri Bakanı Hina Rabbani Khar'ın, bazı mesajların kendi adıyla dolaştırılmasının kurbanı olduğu iddia edilmektedir (Michaelsen, 2011, 43-57). Hatırlanacağı üzere Blitz Weekly adlı gazetede, evli ve iki çocuk annesi Khar'ın Bilaval Butto-Zerdari ile ilişkisi olduğu yazılmıș, ikilinin sürekli mesajlaştıkları iddia edilmişti (Milliyet, 29.09.2012).

Haberin sosyal medyadaki dezenformasyonu düşünüldügünde, tematik bir oydaşmadan söz edilemez. Öyle ki sosyal medya üzerinden paylaşılan ve yayılan siyaset, eğitim, din gibi hemen her konuda dezenformasyon gerçekleşebilmektedir. Bugün kapitalizm tarafından içi boşaltıldığı söylenen sağlık (Gür, 2010, 313) konusunda dâhi dezenformasyon yapılmaktadır. Avrupa'da olduğu gibi Türkiye'de de dezenformasyonun karşısında duran ve "fact-checking" yani doğruluk kontrolü yapan girişimler vardır. Bu girişimler dolaşıma sokulan içerik, söylem ve iddiaların doğruluğunu araştırmakta ve ölçmektedir. Türkiye'deki girişimlerden Doğruluk Payı, Yalansavar, teyit.org ve Malumatfuruş, Foça'nın (2016) detaylıca ele aldığı Reuters Enstitüsü'nün "Digital News Report 2016: The Rise of Fact-Checking Sites" in Europe adlı raporunda belirtilen ikinci tip kategoriye girmekte, yani bir medya kuruluşu altında çalışmamakta, kar amacı gütmemektedir ve göz ettikleri şey doğru haber alma hakkıdır. Bu girişimlerden olan ve doğrulama bağlamında önemli görev gören teyit.org, Mehmet Atakan Foça editörlügünde Türkçeleştirilen Doğrulama El Kitabı'nı da büyük önem atfetmektedir. Çünkü Doğrulama El Kitabı - Kriz Anlarında Dijital Verilerin Doğrulanması İçin Rehber dezenformasyona karşı önemli bir yol gösterici (Foça, 2015). Doğrulama El Kitabı'nda Buttry $(2016,16)$, doğrulamanın "kişinin becerikliliği, ısrarı, şüpheciliği ve yeteneği", "bulunabilen ve konuşmaya ikna edilen kaynakların bilgisi, çeşitliliği ve güvenilirliği" ile "belgelendirme" üzerine kurulu olduğunu söylemektedir. Uyanık ise $(2017,337)$ görsel doğrulaması yapmak (Google'ın görsel arama özelliği bu anlamda önemli) ile ekran görüntüsü almanın (screenshot), içeriğin doğrulanması bağlamında önemli olduğu görüşündedir.

Reuters Gazetecilik Çalışma Enstitüsü'nün “2015 Dijital Haber Raporu”nda incelenen 18 ülke arasında sosyal medyanın \%67'lik bir oranla bir haber kaynağı bağlamında en popüler olduğu ülkenin Türkiye olduğuna dikkat çeken teyit.org, Türkiye'den katılımcıların \%69'luk bir oranla en fazla Facebook'u haber kaynağı olarak kullandıklarını ifade ettiklerini de belirtmektedir. İstasyon TEDU Sosyal İnovasyon Merkezi içinde geliştirilen teyit.org, ilk haber kaynağ olarak interneti kullananların online platformlarda "doğru bilgiye ulaşmasını sağlamayı" ve "eleştirel düşünme alışkanlığını ve doğru bilgiye ulaşma bilincini kazandırmayı" amaçlamaktadır. teyit.org, "Yaygın bilinen yanlışlardan, sosyal medyanın gündemine oturan şüpheli bilgilere, yaygın medyanın gündeme getirdiği iddialardan, şehir efsanelerine birçok alanda doğrulama yaparak okurun süzgeçten geçirilmiş bilgiye ulaşması" adına çalışacağını beyan etmektedir. British Ambassy Ankara, İstasyon, Sivil Düşün $A B$ Platformu'nun destekçileri arasında olduğu teyit.org'a e-posta adresi ile abone 
olunabilmekte, girişimin resmi internet sitesinde (https://teyit.org) Facebook ve Twitter hesapları da görülebilmektedir (https://teyit.org, 2017).

"İnternette yer alan haberleri tarıyor, şüpheli olanları seçiyor, araştırıyor ve sonucunu okurla paylaşıyoruz" diyen teyit.org'un, doğrulama bağlamında izlediği yöntem de şöyledir; ilkin tarama yapılmakta, sonra şüpheli haberler arasında seçim yapılmakta ve bu seçimde virallik, önem ve aciliyet kriterleri rol oynamakta, ardından içerik doğrulama adına temel habercilik yöntemlerini dijital araçlarla kullandıkları bir süreç başlamakta ve araştırma yapılmaktadır. Son olarak ise yapılan araştırma neticesinde yalnızca somut veri ve olguların ortaya konduğu bir analiz oluşmaktadır. $\mathrm{Bu}$ analiz, iddianın ne ölçüde doğrulanıp, ne ölçüde yanlışlandığını anlatmakta ve metin olabildiğince yalın bir dil ile aktarmaktadır. teyit.org, elde ettiği veriler doğrultusunda, incelenen bir iddiaya ilişkin; "doğru", "yanlış", "karma" ve "belirsiz" kategorilerinde sonuçlar ortaya koymaktadır. Bu kategoriler iddianın doğru, yanlış, karma (iddiada hem doğru hem yanlış bilgiler var) ya da belirsiz (iddiaya ilişkin veriler sonuca ulaşmak için yetersiz) olduğunu ortaya koymaktadır. teyit.org'un ilkeleri ise şunlardır; "objektiflik ve açıklık", "düzeltme politikası" ve "ekonomik şeffaflık." Site üzerinden form doldurarak, info@teyit.org ve ihbar@teyit.org e-posta adreslerine mail göndererek ya da 05464745440 numaralı WhatsApp İhbar Hattı aracılığı ile teyit.org'a ulașılabilir (https://teyit.org, 2017).

Türkiye'de fact-checking bağlamında faaliyet gösteren bir diğer girişim de "Malumatfuruş"tur. Malumatfuruş, 2010-2015 yılları arasında Türkiye'nin belki de ilk fact-checking girişimi olduğu iddia edilen ve kendisini "köşe yazarı zabıtası" olarak niteleyen "Muhtesip" adlı köşe yazarı yanlışlama web sitesinin devamı niteliğindedir. Kendini "amatör köşe yazarı yanlışlama girişimi” şeklinde tanımlayan Malumatfuruş, oldukça mütevazî bir kadro ile herhangi bir kâr amacı gütmeksizin faaliyetlerini sürdürmektedir (Kişisel Görüşme/Malumatfuruş Ekibi). Malumatfuruş sitesindeki hakkında kısmında, "İșkembe-i kübrasına güvenerekbol keseden sallayan, bilmeyen, bilmediği hâlde aslını araştırıp doğrusunu öğrenme zahmetine girmeyen köşe yazarlarından haz etmeyenlerin ortak adresidir Malumatfuruş" diyerek dezenformasyon karşıtlığınışöyle ifade etmekte: "Malumatfuruş, okuyucularınayalan yanlış bilgi yutturmaktan ya da manipüle etmekten utanmayan köșe yazarlarından ise haz etmez (Tabiki bu noktada gazetelerin yayın yönetmenlerini ve ilgili kontrol görevlilerini de anmamak olmaz). Yanlışlarını kendi köşelerinde okurlarından özür dileyerek düzeltmeyenlerden ise asla." (http://www.malumatfurus.org, 2017).

Köşe yazarlarının yazılarındaki hata, gaf ve yanlışları ortaya koymayı, dolayısıyla dezenformasyonu karşısına almayı amaçlayan Malumatfuruş, köşe yazılarındaki "nesnel hatalar, gaflar, atlanılan gerçekler ve yanlış yönlendirmelere" odaklandığını söylemektedir.Yayımlanan köşeyazılarının rassalşekildebelirlendiğinin, bubağlamda bir önyargı veya tutumun söz konusu olmadığının altını çizen Malumatfuruş, TDK'ya göre Arapça ve Farsça karışımlı bir sıfat olan isminin anlamının, "bilgiçlik taslayan" olduğunu belirtmektedir. Malumatfuruş'un resmi internet sitesi www.malumatfurus. org, e-posta adresi ise malumatfurus06@gmail.com'dur. Twitter adresi www. twitter.com/malumat_furus, Facebook adresi ise https://www.facebook.com/ malumatfurus06 şeklindedir. Malumatfuruş, kullanıcılarca tespit edilen hususların, kendilerine e-posta ya da site üzerindeki form aracılığıyla ulaştırılabileceğini de ifade etmektedir (http://www.malumatfurus.org, 2017). 


\section{Yeni Bir Dezenformasyon Mecrası Olarak Sosyal Medya}

Yeni bilgi ve iletişim teknolojileri, bireylerin belirli ihtiyaçlarını karşılayacak şekilde tasarlanmıştır (Lievrouw, 2010, 247). Yeni medyanın internet, bilgisayar oyunları gibi birçok ortam ve yeniliği kapsadığı düşünülmektedir (Manovich, 2001). Yeni medyaya dair araçlar, bir ortamda bilgi aktarmak için kullanılan önemli araçlardır (Crosbie, 2002). Kendisini medya literatürüne hızla dâhil eden ve göreceli bir kavram olan (Scolari, 2009, 944-945) yeni medya, bugün konvansiyonel medyanın da yararlandığı bir alan olarak (Güz ve diğerleri, 2015) birçok araştırmaya konu olmaktadır.

Dünya üzerinde bugün internet ve telefon ile bilgi akışı sağlanmayan yer neredeyse yok. Bu yüzden yeni medya söz konusu olduğunda dezenformasyon da kaçınılmaz olmaktadır (Askhita, 2016). Yeni medyanın güç verdiği bir alan olarak sosyal medya ise bugün bireylerin yaşamının vazgeçilmez bir alanını nitelemektedir ve önemli bir dezenformasyon mecrası konumundadır. Örneğin sosyal medyanın avantajlı ve dezavantajlı yanlarının görülebilmesini sağladığı düşünülen Taksim "Gezi Parkı" Olayları sırasında, yoğun bir dezenformasyon süreci yaşandığı iddia edilmektedir (Köseoğlu ve Al, 2013, 114). Gezi Parkı Olayları'nın başlangıcı sosyal medyada ilkin Twitter'da olmuş, ardından tüm sosyal medya mecralarına yayılmıştır (Boomerang İstanbul, 2013). İlk başlarda protestoculara hız kazandıran ve geniş kitlelere kolaylıkla ulaşmalarını sağlayan sosyal medya, sonraları dezenformasyon ile tanışmıştır (Köseoğlu ve Al, 2013: 114). Söz konusu dezenformasyon provakatörler kaynaklı olabilirken, bireylerin bilinçsiz, kontrolsüz ve doğrulanmamıș paylaşımları nedeni ile de olmuştur. Dezenformasyonları engellemek adına sosyal medya hesapları aracılığı ile takipçilerine uyarıda bulunan eylemciler de olmuştur (Boomerang İstanbul, 2013). Bununla birlikte sosyal medyanın, Gezi Olayları'ndan sonra hükümetler için yalnızca bireylerin sosyalleştiği bir mecra olarak görülmemesi gerektiğini savunan yaklaşımlar da vardır (Köseoğlu ve Al, 2013, 114).

Asparagas haberler ile toplumu galeyana getirici, topluma mal olmuş kişilerin hayatlarınıkaybettiğiyönündekiya dayetkililerizanaltındabırakıcıhaberleri/içerikleri sıkça gördügümüz sosyal medyanın, doğruluk ve güvenirlik bağlamında önemli adımlar atması gerektiği de nettir. Sosyal medya dezenformasyonuna karşı kullanıcı çabası ise, şimdilik yalnızca sosyal medyada görülen içeriği, başat konvansiyonel medya organları referans alınarak doğrulama yönünde. Bu durum, haber söz konusu olduğunda, konvansiyonel medyaya duyulan güvenin sosyal medyaya duyulan güvenden daha fazla olduğunu göstermektedir. Dezenformasyon ve misenformasyon aslında çeşitli propaganda faaliyetlerinin kampanya görünümüdür. Doğruluk ve güvenirlik önemli olduğundan kullanıcı, içeriği anlamak ve dezenformasyondan kaçınmak için araştırmakta, doğrulama yapmaya çalışmakta, doğru bilgiye erişmek adına bireysel çaba sarf etmektedir (Kumar ve Geethakumari, 2014).

\section{Dezenformasyona Karşı Yalansavar ve Doğruluk Payı}

Sosyal medyanın oluşumunu hazırlayan Web 2.0 teknolojisidir (Kırık, 2013, 72) ve sosyal medyanın kullanımının hızla artması sebebiyle dezenformasyon gibi misenformasyon da artmıştır. Bu konuda birçok araştırma yapılmıştır ve halen yapılmaktadır. $\mathrm{Bu}$ çalışmada da dezenformasyona karşı duran girişimler olan Yalansavar ve Doğruluk Payı incelenmiștir.

Bir Ortak Gelecek için Diyalog Derneği girişimi olan Doğruluk Payı, “Türkiye'deki siyasi aktörlerin daha sorumlu, seçmenlerin ise doğru bilgiye daha rahat ulaşmasına 
katkı sağlamayı" hedeflemektedir ve tamamen bağımsız bir girişimdir. Doğruluk Payı, ülkedeki siyasiaktörlerin demeçlerini "günlük" takip ettiğini belirtmekte, kamuya açık olan kaynaklar aracılığı ile söz konusu demeçlerin doğruluğunu kontrol etmektedir. Kontrol sonuçlarını yurttaşlar ile paylaşan Doğruluk Payı, "Türkiye'de siyasetten doğruluk talep eden bir topluluk oluşturmayı" amaçladığının altını çizmektedir. Sitesinde (http://www.dogrulukpayi.com) destekçilerini; National Endowment for Democracy, Açık Toplum Vakfı ve European Climate Foundation (Kişisel Görüșme/ Batuhan Ersun tarafından European Climate Foundation'ın düşük bütçeli ve eski bir fon olduğu beyan edildi) şeklinde sıralayan girişim, iletişim bilgilerinde telefon numarasını +902122435963 şeklinde, e-posta adresini ise iletisim@dogrulukpayi. com şeklinde vermektedir. Sitede Doğruluk Payı'nın sosyal medya adresleri de mevcut (http://www.dogrulukpayi.com, 2017). Doğruluk Payı, siyasi aktörlerin iddialarının doğrulamasını beş seviyeden oluşan bir ölçek ile yapmaktadır. İncelenecek iddialar seçilirken; "iddianın doğrulanabilir/yanlışlanabilir nitelikte olması" ile "iddianın görece tartışmalı ve önemli bir konuda olmasına" özen gösterdiğini beyan eden Doğruluk Payı, kontrol bağlamında "iddiada dayanak olarak gösterilen nitel ve nicel verilerin kamuya açık kaynaklardaki verilerle uyuşması", "nitel ve nicel verilerin doğrulandığı/yanlışlandığı kaynakların kalitesi" ile "iddianın söylenme amacı ve bağlamın uygunluğu" kriterlerinde bir değerlendirme yapmakta ve bu kriterler ışığında "Doğruluk Payı Ölçeği”nde farklı beş seviye ortaya çıkmakta, inceleme bu ölçekle yapılmaktadır. Ölçekteki seviyeler ise; “1. ... doğruluk payı vardır, 2. ... kayda değer ölçüde doğruluk payı vardır, 3. ... kısmen doğruluk payı vardır, 4. ... büyük ölçüde doğruluk payı yoktur ve 5. ... doğruluk payı yoktur" şeklindedir (http://www. dogrulukpayi.com, 2017).

Doğruluk Payı, analiz edilecek demeçlerin/iddiaların ulusal medya ajansları ile TBMM ve bağlantılı internet sitelerinden taranarak elde edildiğini söylemektedir. Bir takım iddiaların analizinin farklı uzmanlık alan ve tekniklerini gerektirdiğini de göz önüne alan Doğruluk Payı, "iddialardaki verileri kontrol etmenin yanı sıra iddianın bir seviye arka planındaki nedenselliğin, iddia ve verilerle uyumunu ortaya çıkarmayı" da önemsediğine vurgu yapmaktadır (http://www.dogrulukpayi. com, 2017). Doğruluk Payı'nın cinsiyet, dil, din ya da etnik köken gibi aidiyetlere yönelik ayrımcı dil ve nefret söylemi içeren demeçleri ortaya çıkarmayı, toplumun aydınlanması noktasında önemli bir misyon olarak görmesi de önemlidir (http:// www.dogrulukpayi.com, 2017). Bu yaklaşım, alternatif medyanın çoksesliliği göz eden misyonunun gerçekleștirilmesi bağlamında güncel bir pratiktir.

Doğruluk Payı'nın resmi Twitter hesabının (https://twitter.com/dogrulukpayicom) 5 Şubat 217 tarihi itibariyle 46.919 takipçisi vardır. Doğruluk Payı Twitter'a Mayıs 2014'de katılmış ve konumunu Türkiye olarak belirtmiştir. Hesabında resmi internet site adresini de belirten Doğruluk Payı, paylaşımlarının çoğunu fotoğraf ve videolu yapmaktadır. "Merak ettiklerinizi, analiz edilmesini istediğiniz siyasi demeçleri bize iletebilirsiniz" diyen Doğruluk Payı, Twitter hesabındaki kapak görselinde e-posta, Twitter, Facebook ve WhatsApp iletişim bilgilerini vermektedir. Girişim, internet sitesinde yayınladığı bültenlerde Türkiye'deki bazı istatistiki verilere de yer vermekte ve bunu Twitter hesabından paylaşmaktadır. Örneğin OECD’nin derlediği ve Ekim 2016'da güncellen sağlık verileri ışığında Türkiye'de sigara kullanım oranının erkeklerde \%37,3, kadınlarda ise \%10,7 olduğunun beyan edilmesi ve her yıl ülkelerdeki özgürlük durumlarına dair raporlar sunan Freedom House'un 2016 
verilerini içeren “Dünya'da Özgürlük 2017” adlı raporunda, Türkiye’nin özgürlükler konusundaki durumunun kötüleștiğinin iddia edilmesinin beyan edilmesi, bunlardan bazılarıdır (Doğruluk Payı Bülten- Yazan: Bengi Cengiz, 03.02.2017 ve https:// twitter.com/dogrulukpayicom).

Doğruluk Payı'nın nasıl işlediğini anlamak adına, internet sitesinde açıkladığı ve resmi Twitter hesabından da paylaştığı doğrulamalara bakmakta yarar var. Yapılan analizlerden biri şöyle: T.C. Ekonomi Bakanı Nihat Zeybekci, 26 Ocak 2017'ta Ankara Ticaret Odası'nda yılın ilk ticaret meclisi toplantısına katılmış ve yaptığı konuşmada "Türkiye'nin diş ticaret hacminin 4,5 milyar dolardan 450 milyar dolara yükseldiğini" iddia etmiștir. Bakan'ın iddiasında bir zaman aralığı olmadığından, Doğruluk Payı analizini yaparken, TÜİK verileri ile AK Parti'nin iktidara geldiği 2002'den bugüne kadarki yıllık dış ticaret verilerini incelemiş ve Ekonomi Bakanı Nihat Zeybekci'nin 4,5 milyar dolarlık dış ticaret hacmi iddiasının 70'li yılların başlarına ait olduğunu görmüş ve Türkiye'nin 450 milyar dolarlık bir hacme hiç ulaşmadığı sonucu elde edildiğinden, Bakan'ın iddiasında doğruluk payı olmadığını tespit etmiştir. Bu analizde yararlanılan kaynaklar da (http://www.haberturk.com/ekonomi/isyasam/haber/1369569-bakan-zeybekciden-onemli-aciklamalar ve TÜİK Yıllara Göre Dış Ticaret Verileri) erişme açık şekilde verilmiştir (Doğruluk Payı Beyanat, 30.01.2017- Furkan Demirbaş tarafından 30.01.2017'de eklendi; https://twitter. com/dogrulukpayicom).

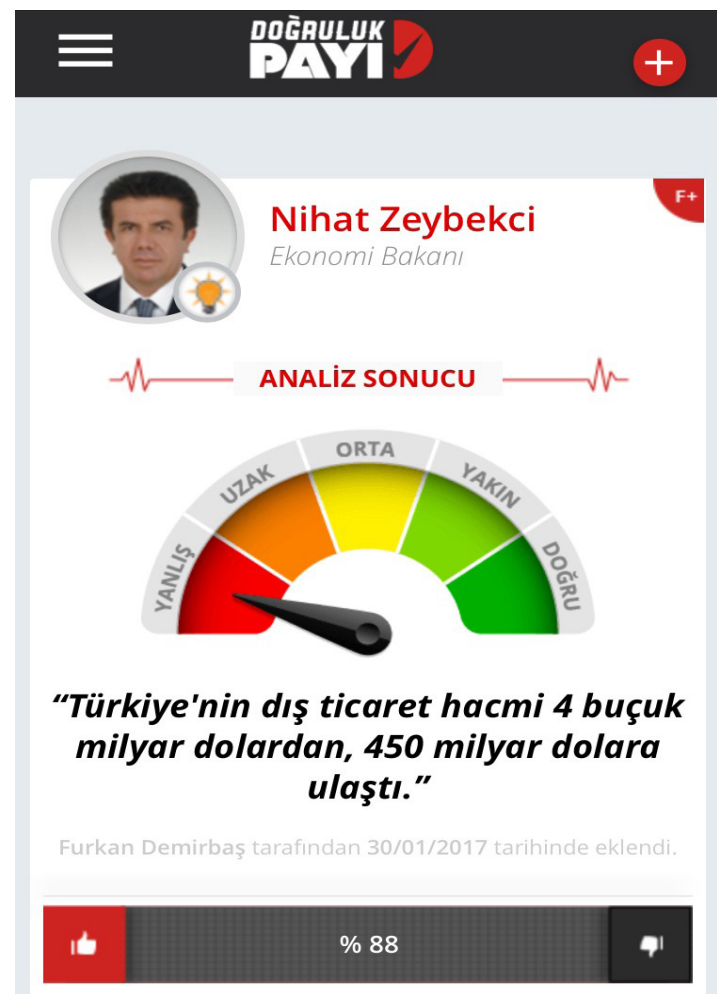

Resim 1: Nihat Zeybekci Demeç, Kaynak: http://www.dogrulukpayi.com

Bir başka örnek de Başbakan Yardımcısı Mehmet Şimșek'in iddiası ile ilgilidir. Şimşek Davos'taki 47. Dünya Ekonomik Forumu'nda "G20 Gündemi: Yeni Büyüme Yolu" başlıklı oturumda konuşmuş ve Türkiye'nin ihracatında AB'nin \%50'lik, ABD’nin ise \%5'lik bir payı olduğunu söylemiştir. Şimşek ayrıca, "Türkiye için AB, ABD'den 10 kat daha önemli bir ticari partner" demiştir. Türkiye'nin ihracatında ABD ve AB'nin paylarını karşılaştırarak bir analiz yapan Doğruluk Payı, TÜİK tarafından, 2016 Kasım 
sonu itibariyle yayınlanan ihracat rakamlarını ele aldığında, Mehmet Şimşek'in açıklamasında doğruluk payı olduğu sonucuna ulaşmıştır. Haber kaynakları; http:// aa.com.tr/tr/ekonomi/basbakan-yardimcisi-simsek-turkiye-icin-ab-abd-den-10kat-daha-onemli-bir-ticari-partner-/730839, TÜİK Ülke Gruplarına Göre İhracat, TÜİK Ülkelere Göre İhracat ve TÜİK Yıllara Göre Dış Ticaret şeklindedir (Doğruluk Payı Beyanat-Furkan Demirbaş tarafından 23.01.2017'de eklendi; https://twitter. com/dogrulukpayicom).

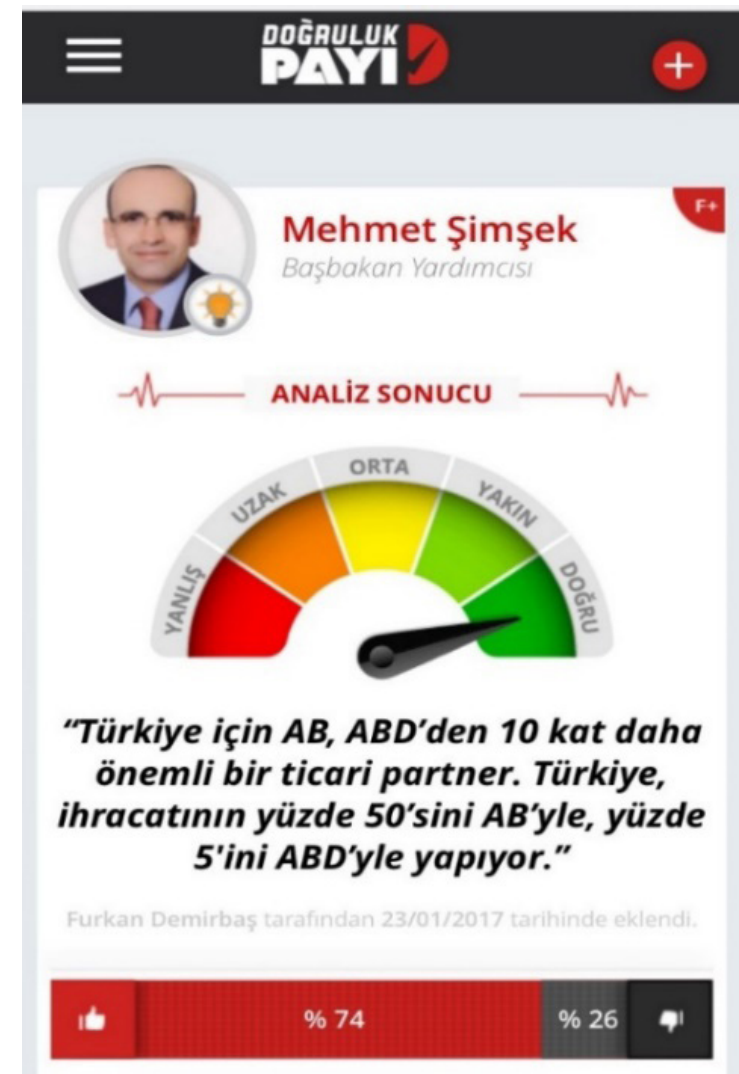

Resim 2: Mehmet Şimşek Demeç, Kaynak: http://www.dogrulukpayi.com

Bir diğer örnek de CHP Genel Başkanı Kemal Kılıçdaroğlu'nun partinin grup toplantısında Özgecan Aslan cinayeti örneğinden hareketle kadın cinayetleri konusuna değinmesi ve 2002 ile 2015 yılları arasında 5406 kadının öldürüldüğünü iddia etmesi ile ilgilidir. Kadın cinayetleri bağlamında bir veri problemi olduğunu söyleyen Doğruluk Payı, Adalet Bakanlığı'nın verdiği bilgiler ve Bianet'in topladığı verilerden 2002 - 2015 arası kadın cinayetleri rakamının 5406 olduğunu belirtmekte, resmi kurumların verilerinden derlenen BM istatistiklerinin ise başka bir tablo sunduğuna dikkat çekmektedir. Buna karşın, Kılıçdaroğlu'nun kullandığı veriyi kadın cinayetlerindeki veri problemi ve BM verileriyle ele alan Doğruluk Payı, iddiada kayda değer ölçüde doğruluk payı olduğunu ifade etmektedir. Analizde yararlanılan kaynaklar ise; http://www.meclishaber.gov.tr/develop/owa/haber_ portal.aciklama?p1=131841, Dönemin Adalet Bakanı Sadullah Ergin'in Soru Önergesine Cevabı (2009) (7 / 8533), Dönemin Adalet Bakanı Sadullah Ergin'in Soru Önergesine Cevabı (2009) (7 / 8533), Dönemin Aile ve Sosyal Politikalar Bakanı Fatma Şahin'in Soru Önergesine Cevabı (2013) (7 / 13271), UNECE Veritabanı, Bianet Verileri, Emrah Göker'in Kadın Cinayetlerindeki Veriler Konusundaki Yazısı şeklinde verilmiştir (Doğruluk Payı Beyanat-Koray Kaplıca tarafından 18.02.2015'te eklendi; https://twitter.com/dogrulukpayicom). 


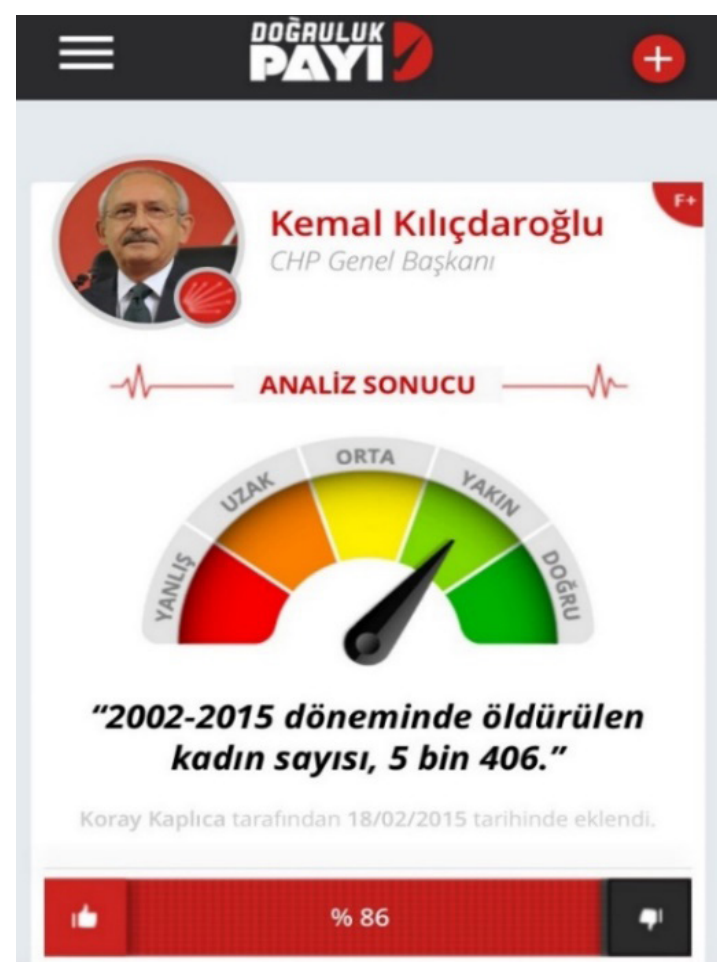

Resim 3: Kemal Kılıçdaroğlu Demeç, Kaynak: http://www.dogrulukpayi.com
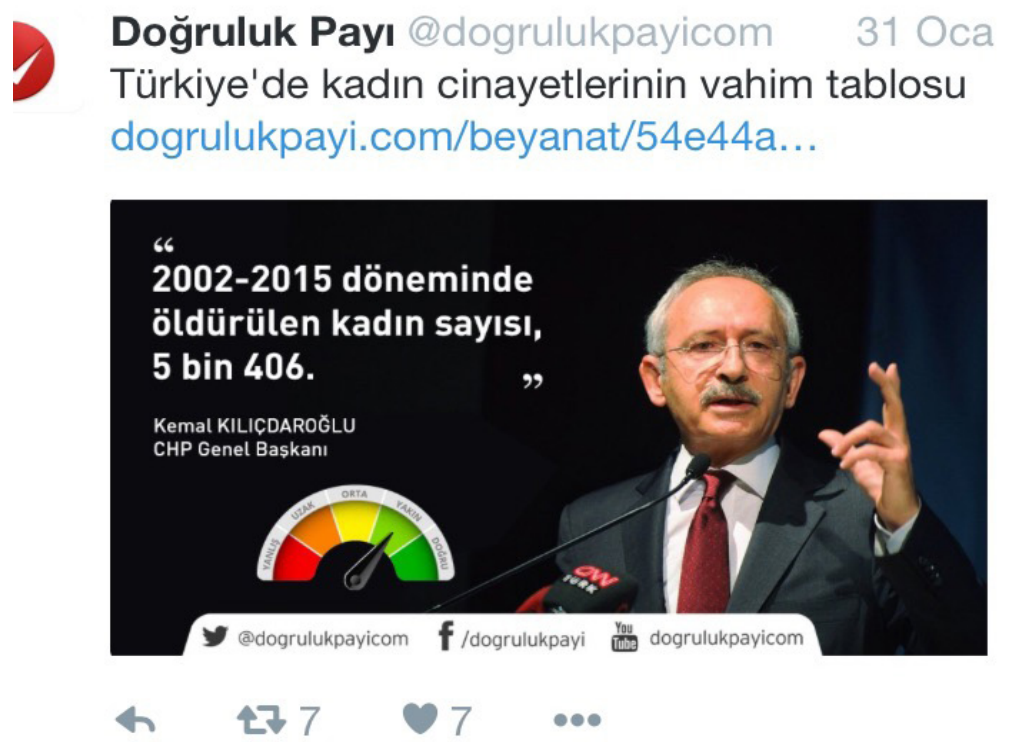

Resim 4: Kemal Kılıçdaroğlu Demeç/Twitter, Kaynak: https://twitter.com/dogrulukpayicom²

Doğruluk Payı sitesinde incelenen iddiaların, konu başlığını (iç politika, sosyal politikalar, adalet vb.), hangi tarihte ve nerede söylendiğini de belirtmektedir (http://www.dogrulukpayi.com, 2017).

Doğruluk Payı, Türkiye'deki siyasi dilin hesap verebilir bir biçim alması ve bu biçimin yaygınlaşması adına çalışmanın en önemli amacı olduğunu söylemektedir. Ocak 2016 itibariyle toplam 175 siyasi aktörün demecini kontrol etmiş olan Doğruluk Payı, söz konusu demeçlerden 550'nin üstünde analiz ortaya koymuștur. Önümüzdeki yıllardaki hedefini "Türkiye'de siyasetin açılış sayfası olmak" șeklinde beyan eden Doğruluk Payı, 2015'te Sabancı Vakfı'nca "Fark Yaratan” seçilmiş, 
Uluslararası Şeffaflık Derneği'nce de “En İyi Sivil Girişim” ödülüne layık görülmüştür (http://ortakgelecek.org/projeler/, 10.02.2017).

"Karanlığa lanet okumaktansa, bir mum yakmak yeğdir" sloganı ile yola çıkan Yalansavar ise "eleştirel düşünce ve bilim tutkunlarının bir araya gelerek oluşturduğu gönüllü bir platform" olduğunu beyan etmekte ve amacının "sağlıklı bir toplum için elzem olan eleştirel düşünce alışkanlığını yaymaya katkıda bulunmak ve muhtelif asılsız iddiaları irdelemek" olduğuna dikkat çekmektedir. Yalansavar bünyesinde, farklı uzmanlık ve ilgi alanlarına sahip olan ve dünyanın birçok yerinde bulunan üyelere yer vermektedir. Yazılarında olabildiğinde güncel ve tarafsız kaynak kullanmaya ve bu kaynakları okurlar ile paylaşmaya özen gösterdiğini söyleyen Yalansavar, içeriklerinde gözlenecek olası önyargıları konusunda da okuyucularından uyarıya açıktır. Çünkü onlara göre, geri bildirimler ile faydalı eleştiriler birer motivasyon kaynağı ve Yalansavar'ın içeriğinin zenginleşmesi ile yazarların fikri gelişimi bağlamında katkı sağlayıcı (https:// yalansavar.org, 2017). Yalansavar ekibi tarafından girișime olabildiğince düzenli katkı sağlandığı belirtilmekte ve bu katkının tamamen gönüllülük esasında olduğunun altı çizilmektedir. Sitenin (https://yalansavar.org) tüm masraflarını Yalansavar ekibinin karşıladığı ve ekipten hiç kimsenin Yalansavar adı altında yürütülen faaliyetlerden maddi bir kazanç elde etmediği ifade edilmektedir. Bununla birlikte Yalansavar, tarafsızlığını zedeleyeceği gerekçesi ile reklam almadığı gibi; başka bir organizasyon, dernek ya da şirketten maddi yahut lojistik destek de kabul etmediğini vurgulamaktadır (https://yalansavar.org, 2017). Yalansavar, Youtube'daki Yalansavar kanalından, Facebook'taki Yalansavar sayfasından ve Twitter'daki @yalansavar kullanıcı adı altındaki hesap aracılığı ile takip edilebilmektedir. Bu kanallar, okuyucuların geri bildirimlerine de açıktır. yalansavar@gmail.com adresine e-posta göndermek sureti ile de geri bildirimde bulunulabilmektedir (https://yalansavar.org, 2017).

Yalansavarın dezenformasyon konusundaki araştırmaları daha fazla gündelik yaşama dair doğru bilinen yanlışlar, safsatalar üzerinedir. Sitede popüler kültür/ gündem, safsatalar/mantık hataları, tıp/sağlık, bilim haberciliği gibi kategorilerde dezenformasyona dikkat çeken yazılar vardır. Sitede "grip ile ilgili doğru bilinen yanlışlar" da anlatılabilmekte (https://yalansavar.org, Işıl Arıcan, 27.01.2017), sayısal veriler ve olağan akıl yürütme ile geçtiğimiz aylarda gündemi bir hayli meşgul eden Yenimahalle'nin sayısal loto başarısına ilişkin iddialar da, doğruluk payı bağlamında tartışılabilmektedir (https://yalansavar.org, Kaan Öztürk, 09.09.2016). Örneğin, Yenimahalle'nin esrarengiz(!) Sayısal Loto başarısı başlıklı yazısı ile sayısal loto tartıșmasını kaleme alan yazara göre, Yenimahalle'nin sayısal loto bağlamında en şanslı ilçe olduğu bilgisi dezenformasyon sonucudur. Çünkü yazar, Sayısal Loto verilerinin 1997 yılına kadar gitmiş olmasına karşın, il/ilçe bilgisinin 2012 yılında başladığını görmüş ve bu verileri elle tek tek toplamak zaman alıcı olduğundan, tarayıcıyı otomatik olarak çalıştırıp her bir haftanın verilerini okuyan ve depolayan bir program yazmıştır. Bu sayede 1 Ocak 2012'den 13 Ağustos 2016'ya kadar, büyük ikramiye çıkan bütün ilçelerin listesini elde eden yazar, bu listeye baktığında Yenimahalle gibi İstanbul'un bir ilçesi olan Kadıköy'e de 9 kez ikramiye çıktığını görmüştür. Öyle ki, Ankara'nın Çankaya ilçesi ile İzmir'in Karşıyaka ilçesine de 8'er kez ikramiye çıkmıştır. Bu ilçelerin, kalabalık ve büyük ilçeler olması ve çok fazla bilet satılmasına binaen, ikramiye çıkma şansı artmaktadır (https://yalansavar.org, 
Kaan Öztürk, 09.09.2016). Buna karşın ilginç ki Yenimahalle ülkedeki en şanslı ilçe olarak lanse edilmektedir ve bu sayede dezenformasyona neden olunmaktadır.

Tablo 1: Yalansavar Yazarının (Kaan Öztürk) Listelediği En Şanslı İlçeler

\begin{tabular}{|l|c|}
\hline IIlçe & Sayısal Loto Büyük İkramiye Sayısı \\
\hline Yenimahalle (Ankara) & 9 \\
\hline Kadıköy (İstanbul) & 9 \\
\hline Çankaya (Ankara) & 8 \\
\hline Karşıyaka (İzmir) & 8 \\
\hline Konak (İmir) & 6 \\
\hline Fatih (İstanbul) & 6 \\
\hline Bornova (İzmir) & 5 \\
\hline Bahçelievler (İstanbul) & 5 \\
\hline Şiși (İstanbul) & 5 \\
\hline
\end{tabular}

5 Şubat 2017 tarihi itibariyle Yalansavar'ın resmi Twitter hesabında (https://twitter. com/yalansavar) 14.580 takipçisi bulunmaktadır ve Yalansavar'ın şu beyanı dikkat çekmektedir: "Skeptisizm ve Eleştirel düşünceyi yaymaya çalışır, Sözde-Bilim, sahte iddialar ve şarlatanlarla savaşır. (A Turkish grassroots skeptical group)" (https:// twitter.com/yalansavar, 2017).

Twitter'a Kasım 2009'da katılan Yalansavar, konumunu İstanbul olarak belirtmekte, tıpkı Doğruluk Payı gibi içeriklerini görsel ve video destekli olarak paylaşmaktadır. Yalansavar okuyucuları ile buluşmalar düzenlemekte, "gönüllü organizasyonların içeriklerinin haberleri ve rızaları olmaksızın kar amaçlı olarak kullanılmasını, paylaşılmasını" kınamaktadır. Yalansavar'ın logosundaki yanan mum görseli, Carl Sagan'ın Karanlığı Aydınlatan Mum Işığı: Bilim adlı kitabından esinlenerek tasarlanmıştır. Yalansavar dinleyiciler için podcast da hazırlamaktadır. Örneğin podcastlarının 10. bölümünde Nobel Hastalığı'ndan, 13. bölümünde ise Grip'ten bahsedilmiştir. Yalansavar podcast'ine, iTunes sayfasından veya http://podcast. yalansavar.org/rss bağlantısından abone olunabilmektedir (https://twitter.com/ yalansavar, 2017).

Bilimsel safsataları yanlışlayan, böylelikle dezenformasyon ile savaşan Yalansavar, düzeltme politikasına da büyük önem vermektedir. Örneğin, CSICON günleri kapsamında Kozmolog Laurence Krauss'un "Metafizikten Fiziğe" başlıklı konuşmasına dair Twitter üzerinden notlar verilirken, bir hata yapılmış ve hata şu tweet ile düzeltilmiştir: "Düzeltme: 389 bin ışılk yılı değil, evrenin 389 bin yıl yaşından önceki hali olacaktı. Gerçek zamanlı çeviri sırasında yanlış yazmışız" (https://twitter. com/yalansavar, 2017).

\section{Sosyal Medya Dezenformasyonu Üzerine Bir Alan Araştırması}

Çalışmada sosyal medya dezenformasyonunu ölçmeyi amaçlayan bir alan araştırması yapılmış, araştırma kapsamında yarı-yapılandırılmış derinlemesine görüşmeler gerçekleştirilmiş, bu yolla çalışmanın varsayımları test edilmiştir. Yöntemi yarıyapılandırılmış derinlemesine görüşme olan bu çalışmanın evrenini, üniversite öğrencileri (gençler) oluştururken; örneklem, sosyal medya kullanıcısı oldukları düşünülen, Beykent Üniversitesi İletişim Fakültesi'nin çeşitli bölümlerinde eğitim gören ve rassal şekilde seçilen toplam 10 öğrenci olarak belirlenmiştir. 
Çalışmanın varsayımları şunlardır:

- Sosyal medya, içeriklerin hızla yayılmasına olanak tanıdığından

dezenformasyonun yayılımını da kolaylaştırmaktadır ve sosyal medya üzerinden yapılan dezenformasyon geniş kitlelere etkileşimli şekilde ulaşmaktadır.

- Sosyal medya dezenformasyonundan kaçınmak için factchecking yani doğruluk kontörlü yapmak gerekmektedir.

- Türkiye'de yeni yeni filizlenen Doğruluk Payı ve Yalansavar gibi bağımsız girişimler fact-checking yapmaktadır ve yıllar içerisinde Doğruluk Payı ve Yalansavar gibi girişimlerin sayısı artacaktır.

- Fact-checking bağımsız girișimler eliyle yapıldığından demokratiktir, objektiftir ve salt kamu yararı gütmektedir.

Derinlemesine görüşme, nitel bir yöntemdir ve araştırmayı yapacak olan kişiye, görüşme yapacağı kişi veya kişilerin görüşlerini derinlemesine analiz etme imkânı sunmaktadır. Derinlemesine görüşmede görüşülecek kişilerin araştırma konusu hakkında bilgi sahibi olması gerekmektedir (Baş ve Akturan, 2008, 111'den akt. Yücetürk, 2012, 57). Bu yüzden bu araştırmada da sosyal medya dezenformasyonu ile ilgili bilgi sahibi olduğu varsayılan 10 katılımcı ile görüşülmüştür.

Görüşmeler 01.04.2017 - 15.04.2017 tarihleri arasında çevrimiçi olarak gerçekleştirilmiştir. Katılımcıların kişisel bilgilerinin açılklanması ya da açıklanmaması konusunda bir çekinceleri, talepleri olmamıştır. Bu yüzden bir kodlama yapılması düşünülmemiştir. Buna karşın, katılımcıların kimlik bilgilerinin açıklanmasının tarafımca gerekli olmadığı düşünüldüğünden, katılımcılar isim ve soy isimlerinin ilk harfleri ile kodlanmıștır.

Görüşülen katılımcıların, yani sosyal medya kullanıcılarının 5’i erkek, 5’i kadındır. Araştırmada cinsiyet bağlamında "belirtmek istemiyorum" seçeneği de sunulmuş, ancak hiçbir katılımcı bu seçeneği işaretlememiştir.

Katılımcıların hepsi 18-25 yaş aralığındadır. Katılımcıların 6'sının aylık gelir düzeyi 1400 TL-2000 TL arasinda, 1'inin 2001 TL-3000 TL, 1'inin de 3001 TL-5000 TL arasındadır. Katılımcılardan 2'si aylık gelir belirtmemiștir.

Katılımcıların 8'i görsel iletişim bölümünde, 1'i Halkla İlişkiler ve Reklamcılık, 1'i ise Görsel İletişim ve Yeni Medya (Türkçe) bölümünde eğitim almaktadır.

Katılımcılardan Ş.B. Periscope hariç tüm sosyal paylaşım platformlarını kullandığını belirtirken, D.K. "Facebook, Twitter ve İnstagramda hesabım var" demiştir. M.İ. ise tüm platformlarda hesabı olduğunu bildirmiştir. C.Y. yalnızca Instagram ve Snapchat'te hesabı olduğunu, H. E. Yalnızca Instagram'da hesabı olduğunu belirtmiştir. S. E. ise hesap sahibi olduğu platformları; Facebook, Twitter, Instagram, SnapChat, Periscope, YouTube, Pinterest, Swarm șeklinde sıralamıştır. K.Ö. Facebook, Twitter, Instagram, SnapChat'de hesap sahibi iken, B.C. sadece Instagram hesabı olduğunu bildirmiştir. B.Ş. Facebook, Twitter ve Instagram hesabı olduğunu, B.B. ise Facebook, Twitter, Instagram ve SnapChat'de hesap sahibi olduğunu bildirmiştir. Kullanıcıların en çok kullandıkları platformlar; Facebook, Twitter, Instagram ve SnapChat.

Kullanıcıların 6'sının fact-checking'den haberi varken, 4'ü konu hakkında bilgi sahibi değildir. 
Katılımcıların 4'ü Türkiye'deki fact-checking girişimlerinden olan ve içerik (haber, iddia vb.) kontrolü, doğrulaması yapan Doğruluk Payı ve Yalansavar hakkında bilgi sahibi iken, 6'sı bu oluşumlar ile ilgili bilgi sahibi değildir. Doğruluk Payı ve Yalansavar'ı Twitter üzerinden takip ediyor musunuz? sorusuna kullanıcıların 1'i sadece Yalansavar'ı takip ettiği yanıtını verirken, diğer 9 kullanıcı ilgili oluşumları Twitter üzerinden takip etmediğini bildirmiştir.

Kullanıcılara sosyal medya dezenformasyonunu en çok nerede gözledikleri sorulduğunda şu yanıtlar alınmıştır: Ş.B., B.C. ve C.Y. soruya Facebook, B.Ş., D.K., H.E., S.E. ve M.İ. Twitter, K.Ö. ve B.B. Twitter ve Facebook yanıtını vermiştir. Yani kullanıcılara göre, sosyal medya dezenformasyonu en fazla Twitter'da söz konusudur.

Araștırma kapsamında sosyal medyadaki içeriklergözönünde bulundurularak, yazarın bir başka çalışmasından da yararlanılarak³ , bir takım içerik temaları/kategorileri oluşturulmuş, katılımcların sosyal medya dezenformasyonunu gözledikleri kategoriler araştırılmıștır. Kategoriler; "aktivizm", "eğitim", "eğlence", "din", "sanat", "siyaset" ve "spor" şeklindedir. Kullanıcıların çoğu, sosyal medya dezenformasyonunun en fazla siyaset kategorisinde söz konusu olduğunu belirtmiştir (Tablo 2). Aktivizm de kullanıcılara göre sosyal medya dezenformasyonunda güncel bir temadır.

Tablo 2: Gözlenen Dezenformasyon Kategorileri

\begin{tabular}{|l|c|}
\hline Kategori & ilıili Kategoriyi Gözleyen Katılımc Sayısı \\
\hline Aktivizm & 3 \\
\hline Eğitim & - \\
\hline Eğlence & 2 \\
\hline Din & - \\
\hline Sanat & - \\
\hline Siyaset & 5 \\
\hline Spor & - \\
\hline
\end{tabular}

Kullanıcılardan Ş.B.'a göre sosyal medya dezenformasyonun sebebi, "insanları birbirine düşürmek isteyen, bundan keyif alan insanların olması. Bir de hit kasmak uğruna gerçekçilikten uzak paylaşımlar yapan çok takipçili kullanıcılar.” D.K ise konu ile ilgili şöyle diyor: "Günümüzde artık insanların ünlü olmaları bir tık'a baklyor. Oldukça meraklı bir toplum olduğumuzdan insanların hayatlarına dâhil olmak bir numaralı vazifemiz haline geldi. Özellikle başkalarının hayatlarında atıp tutmanın prim yaptığı günlerdeyiz. Dolayısıyla yalan prim yapmakta. E ne kadar fazla yalan o kadar fazla takipçi yani bilinirlik." C.Y. ise sosyal medya dezenformasyonu sahte kullanıcılara bağlıyor. S.E. sosyal medya dezenformasyonun amacının algıları yönetmek olduğu görüşünde. M.İ'e göre sebep ise; çıkar ve menfaat. H.E. yalan haberlerin dezenformasyonda önemli rol oynadığı görüşünde iken, K.Ö. şöyle diyor: "Sebep çok fazla ve hızlı içerik paylaşımı. İçerik paylaşımı bu denli hızlı ve yığınla olunca, hangi haber doğru, hangisi yalan kontrol edemiyorsunuz. B.C. "Bana göre sosyal medya dezenformasyonunun sebebi dikkat çekmeye çalışmak olabilir." B.Ş., sahte kullanıcı hesaplarının fazla bulunması ve kaynağı kontrol edilmeden yapılan içerik paylaşımlarının sosyal medya dezenformasyonunda rol sahibi olduğunu düşünmektedir. B.B. ise konuyla ilgili şunları söylemektedir: "Çok fazla bilgi paylaşımı olmasından dolayı insan artık hangisi doğru hangisi yalan ayırt edemiyor. Sahte hesaplar da çok fazla var. Bu konuda bilinçlenmek lazım. Bilinçsiz kullanıcılar, içeriğin doğruluğunu kontrol etmeden yayıyorlar, böylece yalan bilgi daha fazla yayılıyor." 
Katılımcılar, Doğruluk Payı ve Yalansavar sosyal medya dezenformasyonu noktasında yeterli oranda çalışıyor mu? sorusuna şöyle yanıtlar vermiştir: Ş.B. "Fikrim yok, ama çalışıyorlardır herhalde." derken, D.K. "Doğruluk Payı hakkında bir bilgim yok ancak Yalansavar'ın bu konuda çalıştığına inanıyorum. Kendileriyle 2015'te Mirgün Cabas'ın programı vasıtasıyla tanışmıştım. Çok güzel bir iş yapıyorlar. Geç tanıdığım için pişmanım :)" demiştir. M.İ. ve C.Y. konu hakkında görüş bildirmek istememiştir. H.E., S.E., K.Ö., B.Ş., B.B. ve B.C. Doğruluk Payı ve Yalansavar'ın sosyal medya dezenformasyonu noktasında yeterli oranda çalışmadığı görüşünde.

Katılımcıların hepsi, Doğruluk Payı ve Yalansavar gibi girişimlerin sayısının artması gerektiği görüşünde. Öyle ki B.B. "İçerik doğrulaması uygulamaları artmalı." derken, S.E. "Şayet insanlar sosyal medya üzerinden aldıkları enformasyonun büyük oranının dezenformasyon olduğunu fark ederlerse, bu tarz girişimlere talep daha fazla olur ve sayıları artar." demiştir.

Sosyal medyada hızla yayılan dezenformasyonun önüne nasıl geçilebilir? sorusuna katılımcıların verdiği yanıtlar şöyledir: Ş.B. "Önce insanların bilinçli bir şekilde sosyal medya kullanmayı öğrenmesi lazım. Zamanla olur." demiştir. D.K. ve B.B. görüş bildirmemiș, M.İ. "Doğruluk payını arttırıcı veriler ortaya konmalı diye düşünüyorum." derken, C.Y. "Hükümetler kontrol edebilir." yanıtını vermiştir. H.E. ise "Her kullanıcı tükettiği içeriği kendi kontrol etmeli." derken, S.E. "Sosyal medyada tüketilen bilgi çok hızlı. Okuduğumuz haberin doğruluğuna hemen inanıyoruz, paylaşıyoruz. Ve istemeden de olsa viral olarak yayılmasını sağlıyoruz. Bir haberin ise doğruluğunu veya yanlışlığını tespit etmek biraz zaman alabilir. Dezenformasyonun tamamen önüne geçilemese de fact-checker'larla bir nebze kontrol edilebilir." demiştir. K.Ö. kullanıcıların içeriği kendilerinin kontrol etmeleri gerektiği görüşündedir. B.C. ise "Hızla yayılan sosyal medya dezenformasyonunun önüne bilinçlenerek, her gördüğümüze inanmayarak, doğruluklarını araştırarak geçebiliriz." demiştir B.Ş.'nin yanıtı ise "Kullanıcılar bilinçlenerek geçebilirler." şeklindedir. Katılımcılar, doğru haber alma hakkı bağlamında fact-checking'i bağımsız girişimlerin yapıyor olması demokratik ve objektif midir? Sizce kamu yararını göz etmekte mi? sorusunu da yanıtlamışlardır. Katılımcılardan D.K. ve B.B. konu hakkında görüş bildirmezken, Ş.B. "Evet, objektiftir. Kamu yararını gözetmese de olur, olanı söylesin yeter." demiș, M.İ. de "Kamu yararını gözetmekte bence. Objektif olduğunu düşünüyorum." demiștir. K.Ö., B.C., B.Ş., C.Y. ve H.E. fact-checking'i bağımsız girișimlerin yapıyor olmasını demokratik ve objektif bulduğunu, kamu yararı göz edildiğini belirtmiştir. S.E. ise "Bağımsız girişimlerin yapmasını daha demokratik ve objektif buluyorum. Cünkü devlet fonlu veya büyük medya kuruluşlarının vasıtasıyla yapsalardı mutlaka baskı, manipüle etme veya kontrol altına alma durumu olurdu. Kamu yararını koruyacağını düşünüyorum." şeklinde görüş bildirmiştir.

\section{Sonuç ve Öneriler}

Çalışmada incelenen Doğruluk Payı ve Yalansavar gibi, diğer doğrulama organizasyonları olan teyit.org ve Malumatfuruş da kendisini organizasyon yerine, "girişim" ifadesi ile tanımlamaktadır. Koordinatörü Batuhan Ersun'un Ortak Gelecek İçin Diyalog Derneği'nin bir projesi olduğunu söylediği Doğruluk Payı, “Türkiye'de siyasi aktörlerin vatandaşlara karşı sorumlu, seçmenin ise siyaseten daha bilgili olmasına katkı sağlamayı" amaçladığından, siyasal bilgilenmeye de büyük katkı sunmaktadır. Haziran 2014'ten beri çalışmalar yapan Doğruluk Payı, bu katkıyı "değerler siyasetinden veriler siyasetine geçiş ortamı yaratmak" biçiminde 
yorumlamaktadır. ${ }^{4}$ Özellikle sosyal ağlarda yoğun olarak gözlenen sahte içerikler sebebi ile çevrimiçi yayınlanan içerikler, bugün her an teyide muhtaç durumda. Örneğin 22.05.2017'de İngiltere'nin Manchester kentinde Ariana Grande konserinde meydana gelen patlaması sonrası şarkıcının yaralı haldeki fotoğrafları sosyal medyada yayılmış, fakat ilgili fotoğrafın iki yıl önce bir film setinde çekilmiş olduğu anlaşılmıştı. ${ }^{5}$

$\mathrm{Bu}$ çalışmada da araştırmaya katılan katılımcıların kanaatlerinden anlaşılmıştır ki, doğruluk kontrolü, özellikle sosyal medya ayağı ile bugün önemli bir yerdedir. 10'undan 8'inin görsel iletişim bölümünde eğitim aldığı katılımcıların hepsinin sosyal medya kullanıcısı olmasına karşın, Doğruluk Payı ve Yalansavar'dan çok haberdar olmamaları önemlidir. Bu durum doğruluk kontrolü organizasyonlarının Türkiye'de yeni yeni filizlendiğine işaret etmektedir. Buna karşın, katılımcıların çoğunun sosyal medya dezenformasyonu konusunda bilgisi var ve kullanıcılar ilgili durumun sebebini, sahte içerik ve kullanıcıların sosyal medyadaki yoğunluğu olarak görmekteler. Katılımcıların çoğu Doğruluk Payı ve Yalansavar'ın sosyal medya dezenformasyonu noktasında yeterli oranda çalışmadığı görüşünde. Katılımcıların bu oluşumların sayılarının artmaları gerektiği yönünde görüş bildirmesi de önemli. Bir başka önemli olan durum da, doğru haber alma hakkı anlamında kendimizin içerik kontrolü, doğrulaması yapması gerektiği. Katılımcılar fact-checking'i bağımsız girișimlerin yapıyor olmasını demokratik ve objektif bulurken, kamu yararı göz ettiğini de düşünmekteler.

Katılımcılara göre, sosyal medya dezenformasyonu kendisini Facebook ve Twitter'da daha fazla göstermektedir ve baskın tema siyasettir. Onlara göre, sosyal medya dezenformasyonu en fazla Twiter'da söz konusudur. Sosyal medya, içeriklerin hızla yayılmasına olanak tanıdığından, dezenformasyonun yayılmasını da kolay ve hızlı kılmakta.

Sonuç olarak, özellikle sosyal medyada içerik doğrulama her zaman mümkün olmadığından, dezenformasyonun hem meslek etiği, hem de kamu yararı bağlamında bir sorun teşkil ettiği ortada. Doğruluk Payı ve Yalansavar gibi girişimler bunun önüne geçmek için adımlar atsalar da, varlıklarını ve amaçlarını daha fazla kitleye duyurmak mecburiyetindeler. Sosyal medya üzerindeki enformasyon akışı ve adeta bombardımanı her gün hızla artarken, kullanıcı olarak yapılması gereken ise sosyal medya üzerinden dolaşıma sokulan içerikleri elden geldiği ölçüde doğrulamaya çalışmak. Unutmamalı ki her türlü enformasyonu kontrol eden de, popülerleştiren de bireyin kendisi. Bu yüzden kullanıcı olan birey, dezenformasyonu tanımalı ve onu faydalı içerikten ayırt edebilmelidir.

\section{Notlar}

${ }^{1}$ Bu çalışmada yer verilen ve Doğruluk Payı'nın resmi internet sitesinden elde edilen resimlerin alt kısmındaki yüzdelik, Siz İnandınız mı? sorusuna verilen cevaplar ışığında okuyucuların iddiaya ne oranda inandığını göstermektedir. Kırmızı işaret katılıyorum'u, siyah olan ise katılmıyorum'u refere etmektedir.

${ }^{2}$ Kılıçdaroğlu'nun demeci 2015 yılına aittir ve Doğruluk Payı'nın internet sitesine 18.02.2015’te eklenmiştir. Buna karşın aynı iddia, Doğruluk Payı'nın Twitter hesabında 31 Ocak 2017 tarihinde de paylaşıımıştır (Bkz Resim 4).

${ }^{3}$ Yegen, C. (2015).Yurttaş Gazeteciliği Yapan Alternatif Medya Kuruluşu Örneklerinden Hareketle Gazeteciliğin Geleceği Üzerine Bir İnceleme, Twitter IIletişim Çalışmalarında Dijital Yaklaşımlar içerisinde, ss.183-223, (Ed. Özge Uğurlu \& Selva Ersöz Karakulakoğlu) Heretik: Ankara.

${ }^{4} \mathrm{http}: / /$ ortakgelecek.org/projeler/, 10.02.2017.

${ }^{5}$ http://www.hurriyet.com.tr/ingilteredeki-patlama-videoda-iste-0-korku-dolu-dakikalar-40466537. 


\section{Kaynaklar}

Algül, A. ve Sütcü, S. C. (2015). Değișen Haber Algısı: Kullanıcılar Sosyal Medyada Haberleri Nasıl Değerlendiriyorlar?. Global Media Journal TR Edition 6 (11): 18-34.

Askhita, H. (2016). Disinformation in news reporting in the current crisis of Syria. Web: http://blogs.sub.uni-hamburg.de/ifla-newsmedia/wp content/ uploads/2016/04/Askhita-Disinformation-in-News-Reporting-in-theCurrent-Crisis-of-Syria.pdf. Erişim: 04.01.2017.

Boomerang İstanbul. (2013). Social Media \& Mobile Marketing. Gezi Parkı Dosyası. Web: http://boomerangistanbul.com/wp-content/uploads/2013/07/ Boomerang-GeziParkiDosyasi.pdf. Erişim: 30 Ocak 2017.

Buttry, S. (2016). Bölüm 2: Doğrulamanın Temelleri: Uyulması Gereken Kurallar. Doğrulama El Kitabı içinde. Ed. M. Atakan Foça. Çevirmenler: Gürkan Özturan, Gülșah Deniz, Emre Sorkun, Onurcan Önal, Berk Göbekcioğlu.

Crosbie, V. (2002). What is New Media?. Web: www.digitaldeliverance.com. Erişim: 1 Ocak 2017.

Doğruluk Payı. (2015). "2002-2015 döneminde öldürülen kadın sayısı, 5 bin 406.”. Web: http://www.dogrulukpayi.com/beyanat/54e44aa24f8cc. Erişim: 18 Şubat 2015.

Doğruluk Payı. (2017). Hakkımızda. Web: http://www.dogrulukpayi.com/ hakkimizda. Erişim: 30 Ocak 2017.

Doğruluk Payı. (2017). “Türkiye'nin dış ticaret hacmi 4 buçuk milyar dolardan, 450 milyar dolara ulaştı.". Web: http://www.dogrulukpayi.com/ beyanat/588eecd7b00c5. Erişim: 30 Ocak 2017.

Doğruluk Payı. (2017). “Türkiye için AB, ABD'den 10 kat daha önemli bir ticari partner. Türkiye, ihracatının yüzde 50'sini AB'yle, yüzde 5>ini ABD’yle yapıyor." Web: http://www.dogrulukpayi.com/beyanat/5885e0441daa3. Erişim: 23 Ocak 2017.

Foça, A. M. (2015). Doğrulama El Kitabı Türkçe Yayında!. 17.08.2015. Web: http:// matakanfoca.com/dogrulama-el-kitabi-turkce-yayinda/. Erişim: 29 Aralık 2016.

Foça, A. M. (2016). Avrupa'da fact-checking: doğrulama demokrasinin yeni bekçisi mi?. 08.12.2016, Web: https://teyit.org/avrupada-fact-checking-dogrulamademokrasinin-yeni-bekcisi-mi/. Erişim: 29 Aralık 2016.

Greenslade, R. (2017). Facebook is trying to tackle fake news, but what should we do?. Web: https://www.theguardian.com/media/greenslade/2017/jan/26/ facebook-is-trying-to-tackle-fake-news-but-what-should-we-do. Erişim: 26 Ocak 2017.

Gür, G. E. (2010). Dezenformasyona Uğratılan Bir Hak Olarak Sağlık. II. Sosyal Haklar Ulusal Sempozyumu (SHUS-II 2010). ss. 299-313.

Güz, N. (2005). Haberde Yönlendirme ve Kamuoyu Araştırmaları. Ankara: Nobel Yayınları. 
Güz, N.; Yegen, C. ve Yanık, H. (2015). New Media and Journalism in Turkey: A Comparative Analysis on Twitter Usage Practices of Yeni Şafak and Sözcü Newspapers. Shaping the Future of News Media, the International Conference on Integrated Journalism Education, Research and Innovation. 17 - 19 June 2015. Pompeu Farba University. Barcelona.

Güz, N.; Yegen, C. ve Yanık, H. (2017). New Media as News and Information Source: Sample of Muş Province. 3rd International Conference on Social Sciences and Education Research. April 27-29, 2017. Rome, ITALY.

Hürriyet.com.tr. (2017). "İngiltere'deki patlama sonrası yalan haberler yayılıyor". 23.05.2017. Web: http://www.hurriyet.com.tr/ingilteredeki-patlamavideoda-iste-o-korku-dolu-dakikalar-40466537. Erişim: 24 Mayıs 2017.

Kırık, A. M. (2013). Gelişen Web Teknolojileri ve Sosyal Medya Bağımlılığı. Sosyal Medya Araştırmaları I: Sosyalleşen Birey içinde. ss. 69-102. Ali Büyükaslan \& Ali Murat Kırık (Ed). Konya: Çizgi Kitabevi Yayınları.

Köseoğlu, Y. ve Al, H. (2013). Bir Siyasal Propaganda Aracı Olarak Sosyal Medya. Akademik Íncelemeler Dergisi 8 (3): 103-125.

Kumar, K. ve Geethakumari, G. (2014). Detecting Misinformation in Online Social Networks Using Cognitive Psychology. Human-centric Computing and Information Sciences 4: 14.

Kux, D. (1985). Soviet Active Measures and Disinformation: Overview and Assessment. Parameters: Journal of the USA Army War Collage 15 (4): 19-28.

Lievrouw, A L. (2010). New Media Design and Development: Diffusion of Innovations v Social Shaping of Technology. In Handbook of New Media - Social Shaping and Social Consequences of ICTs, Updated Student Edition, pp. 246-265. Ed. Leah A. Lievrouw \& Sonia, Livingstone. Sage Publications.

Livingstone, S. (1999). New Media, New Audiences?. New Media \& Society 1 (1): 59-66.

Malumatfuruş. (2017). Hakkında. Web: http://www.malumatfurus.org/hakkinda/. Erişim: 1 Mart 2017.

Manovich, L. (2001). The Language of New Media. MIT Press.

Michaelsen, M. (2011). New Media vs. Old Politics - The Internet, Social Media, and Democratisation in Pakistan. fesmedia Asia Series. Published by fesmedia Asia Friedrich-Ebert-Stiftung. Germany: Berlin.

Milliyet. (2012). 'Yasak aşk' Pakistan'ı karıștırdı. Web: http://www.milliyet.com.tr/yasak-ask-pakistan-i-karistirdi/dunya/dunyadetay/29.09.2012/1604091/ default.htm. Erişim: 1 Mart 2017.

O'Brien, N. T. (1989). Russian Roulette: Disinformation in the U.S. Goverment and News Media. Submitted in Partial Fulfillment of the Requirements for the Degree of Master of Arts in the College of Journalism and Mass Communications University of South Carolina.

Ortak Gelecek İçin Diyalog Derneği. (2017). Projeler (Doğruluk Payı). Web: http:// ortakgelecek.org/projeler/. Erişim: 1 Mart 2017.

Scolari, A. C. (2009). Mapping Conversations about New Media: the Theoretical Field of Digital Communication. New Media \& Society 11 (6): 943-964. 
Shoemaker, J. P. ve Reese, D. S. (1996). Mediating the Message: Theories of Influences on Mass Media Content. Second Edition. Longman USA.

Silverman, C. (2016). Here Are 50 Of The Biggest Fake News Hits On Facebook From 2016. Web: https://www.buzzfeed.com/craigsilverman/top-fake-news-of2016?utm_term=.lgW99N2nA\#.kr377ZlQ9. Erişim: 30 Aralık 2016.

Teyit.org. (2017). Nedir?. Web: https://teyit.org/nedir/; www.teyit.org/metodolojive-ilkeler/. Erişim: 10 Şubat 2017.

Tuchman, G. (1973). Making News by Doing Work: Routinizing the Unexpected. American Journal of Sociology 79 (1): 110-131.

Tudjman, M. ve Mikelic, N. (2003). Information Science: Science about Information, Misinformation and Disinformation. Informing Science InSITE - "Where Parallels Intersect" June 2003.

Tunç, A. (2010). Medya ve Bilgi Kirliliği, in Tarihi Miras ve Beklentiler Arasındaki Türkiye. Konrad Adenauer Shiftung e. V, Ankara. 2010, pp. 245-250.

Turner, F. (2009). Burning Man at Google: A Cultural Infrastructure for New Media Production. New Media \& Society 11 (1\&2): 73-94.

Twitter. (2017). Doğruluk Payı. Web: https://twitter.com/dogrulukpayicom?lang=tr. Erişim: 27 Ocak 2017.

Twitter. (2017). Yalansavar. Web: https://twitter.com/yalansavar. Erişim: 27 Ocak 2017.

Ura, M. (1980). Making The News: A Guide To Using The Media. Vancouver: West Coast Enviromental Law Research Foundation.

Uricchio, W. (2009). Moving Beyond the Artefact - Lessons From Participatory Culture. in Digital Material - Tracing New Media in Everyday Life and Technology. pp. 135-146. Ed. Marianne van den Boomen, Sybille Lammes, Ann-Sophie Lehmann, Joost Raessens \& Mirko Tobias Schäfer. Amsterdam University Press.

Uyanık, Ş. (2017). Mobil Teknolojiler Sayesinde Hızla Yayılan Sahte Haberlerle Başa Çıkmanın Yöntemleri: Bilgi Doğrulama Üzerine Bir Araştırma. Tüm Boyutlarıyla Internet Haberciliği içinde. (Ed. Berrin Kalsın), ss. 333-348. Gece Kitaplı̆̆ , Ankara.

Vaisey, S. (2008). Socrates, Skinner, and Aristotle: Three Ways of Thinking About Culture in Action. Sociological Forum 23 (3): 603-613.

Yalansavar. (2016). "Yenimahalle’nin esrarengiz(!) Sayısal Loto bașarısı”. 09.09.2016. Web: https://yalansavar.org/2016/09/09/yenimahallenin-esrarengizsayisal-loto-basarisi/, Erişim: 09 Eylül 2016.

Yalansavar. (2017). Hakkımızda. Web: https://yalansavar.org/yalansavar-siksorulan-sorular/, Erişim: 27 Ocak 2017.

Yegen, C. (2015). Yurttaş Gazeteciliği Yapan Alternatif Medya Kuruluşu Örneklerinden Hareketle Gazeteciliğin Geleceği Üzerine Bir İnceleme, Twitter İletişim Çalışmalarında Dijital Yaklaşımlar içerisinde, ss.183 - 223, (Ed. Özge Uğurlu \& Selva Ersöz Karakulakoğlu) Heretik, Ankara. 
Yücetürk, E. E. (2012). İşyerlerindeki Yıldırma Eylemlerini Önlenmede Sendikaların Rolü: Nitel Bir Araștırma. Çalışma ve Toplum. 2012/4. ss. 41-71.

Wakabayashi, D. ve Isaac, M. (2017). In Race Against Fake News, Google and Facebook Stroll to the Starting Line. Web: https://www.nytimes.com/2017/01/25/ technology/google-facebook-fake-news.html?

\section{Kişisel Görüşmeler}

Doğruluk Payı - Koordinatör, Batuhan Ersun ile kişisel iletişim, 11 Şubat 2017

Yalansavar, Dr. Işıl Arıcan ile kişisel iletişim, 27 Ocak 2017

Malumatfuruş Ekibi ile kişisel iletişim, 1 Mart 2017

\footnotetext{
"Yazar 10.02.2017 tarihinde kurumsal e-posta adresinden teyit.org'a doğruluk kontrolü ve dezenformasyon konusunda bilgi almak adına e-posta göndermiş (info@teyit.org), oluşumdan herhangi bir yanıt alamamış, bu sebepten herhangi bir teyit.org yetkilisi ile kişisel görüşme gerçekleştirilememiştir.
} 
